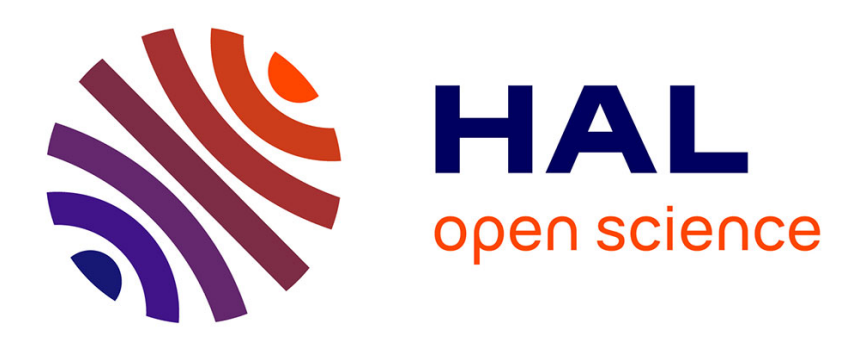

\title{
Phase transitions in layer-intercalation compounds of nickel cyanide with n-alkylamines
}

\author{
Y. Mathey, C. Mazières
}

\section{To cite this version:}

Y. Mathey, C. Mazières. Phase transitions in layer-intercalation compounds of nickel cyanide with n-alkylamines. Journal de Physique Lettres, 1975, 36 (10), pp.243-245. 10.1051/jphyslet:019750036010024300 . jpa-00231198

\section{HAL Id: jpa-00231198 https://hal.science/jpa-00231198}

Submitted on 1 Jan 1975

HAL is a multi-disciplinary open access archive for the deposit and dissemination of scientific research documents, whether they are published or not. The documents may come from teaching and research institutions in France or abroad, or from public or private research centers.
L'archive ouverte pluridisciplinaire HAL, est destinée au dépôt et à la diffusion de documents scientifiques de niveau recherche, publiés ou non, émanant des établissements d'enseignement et de recherche français ou étrangers, des laboratoires publics ou privés. 
Classification

Physics Abstracts

$7.150-7.480-7.130$

\title{
PHASE TRANSITIONS IN LAYER-INTERCALATION COMPOUNDS OF NICKEL CYANIDE WITH $n$-ALKYLAMINES
}

\author{
Y. MATHEY and C. MAZIÈRES \\ Laboratoire de Physicochimie Minérale, Université Paris Sud, 91405 Orsay, France
}

(Reçu le 29 mai 1975, accepté le 26 juin 1975)

\begin{abstract}
Résumé. - On met en évidence l'existence de deux étapes dans la désorganisation par chauffage du système de chaînes paraffiniques intercalées entre les couches tétracyanonickélate de $\mathrm{Ni}$ du composé cyanure de $\mathrm{Ni}-\boldsymbol{n}$ dodécylamine. Les spectres IR et de diffraction X subissent d'importantes modifications aux environs de 55 et de $90{ }^{\circ} \mathrm{C}$, les enthalpies de transitions correspondantes (solidesolide et solide-liquide respectivement) étant approximativement dans le rapport $4: 1$. La série comportant des alkylamines normales en $\mathrm{C}_{n}$ est étudiée pour $n=12$ à 16 : on montre l'influence sur la première transition de la parité du nombre d'atomes de carbone de la chaîne paraffinique.
\end{abstract}

\begin{abstract}
A two step modification phenomenon is observed, upon heating, within the intercalated chain system of the nickel cyanide- $n$ dodecylamine compound : strong modifications of both X-ray diffraction patterns and IR spectra take place at 55 and $90^{\circ} \mathrm{C}$. The enthalpy of the observed transitions (respectively solid-solid and solid-liquid) are roughly in the ratio 4 to 1 . The study of $n$ alkylamines compounds from dodecyl to hexadecylamine shows that the parity of the number of $\mathrm{C}$ atoms of the alkylamine chain has a significant effect on the first transition.
\end{abstract}

The ability of systems such as graphite [1], chalcogenides $[2,3]$, silicates $[4,5]$ to intercalate molecules within their layer lattices is well known. It is also known [6-10] that bonding of various molecules by their polar end-groups to the $\mathrm{N}$-coordinated $\mathrm{Ni}$ atoms of nickel cyanide complexes leads to solid layer intercalation compounds showing definite interlayer spacing. By examining compounds with $n$ from 2 to 18 at two or three temperatures Walker and Hawthorne [11] have pointed out the ability of $n$-alkylamine chains thus intercalated (Fig. 1) to demonstrate a liquid-like or crystal-like structural character.

By studying compounds from $n=12$ to $n=16$ in the temperature range $-120^{\circ} \mathrm{C}$ to $130^{\circ} \mathrm{C}$, we were able to find a solid-solid transition within the intercalated chain system, prior to the melting of the chains.

Preparations of form I (see below) of the Ni cya-

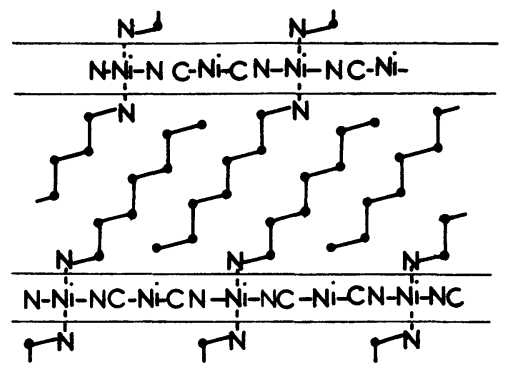

Fig. 1. - Proposed structure of an $n$-alkylamine nickel cyanide complex after Weiss 1958 . nide- $n$ alkylamine compound in the $1: 1$ ratio for $\mathrm{Ni}(\mathrm{CN})_{2} / \mathrm{C}_{n} \mathrm{H}_{2 n+1} \mathrm{NH}_{2}(n=12$ to 16$)$ will be reported elsewhere [12].

Taking $n=12$ as an example, the differential thermal analysis (DTA) shows, without any loss of mass, a remarkably simple thermogram consisting of two endotherms starting around $55^{\circ} \mathrm{C}$ and $90^{\circ} \mathrm{C}$, thus defining the domains of three distinct forms (I, II, III) of the complex (Fig. $2 A$ ).
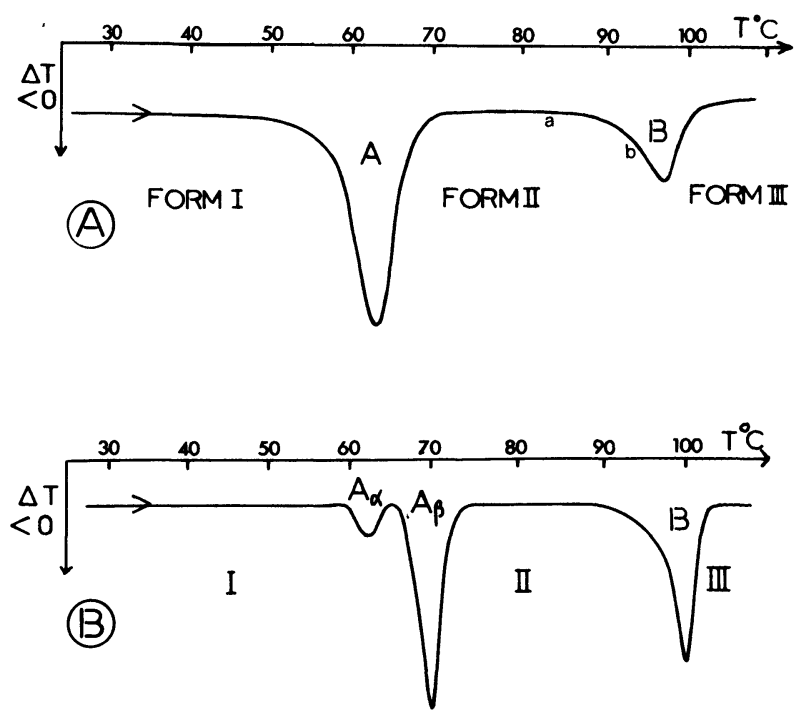

FIG. 2. - DTA thermograms : A : $\mathrm{C}_{12} \mathrm{H}_{25} \mathrm{NH}_{2}$ compound; B : $\mathrm{C}_{13} \mathrm{H}_{27} \mathrm{NH}_{2}$ compound. 
The weaker signal, around $90^{\circ}$ (transition II $\rightarrow$ III), is reversible on cooling regardless of the cooling rate. The recovery of form I on cooling can also be detected by DTA : the process takes hours in the range $30-50^{\circ} \mathrm{C}$, but is much faster at lower temperatures. Estimation of the enthalpies by peak-area measurement leads to values of $0.45 \mathrm{cal}$ and $0.12 \mathrm{cal}$ per methylene group of amine $\mathrm{C}_{12} \mathrm{H}_{25} \mathrm{NH}_{2}$ respectively for transitions I $\rightarrow$ II and II $\rightarrow$ III ; the same procedure leads to a value of 0.92 cal per $\mathrm{CH}_{2}$ group for the melting of the pure amine.

The most striking change on heating from $I$ is the progressive disappearance of the splitting of two infra-red bands which can be ascribed to intra-chains vibrations (Table I). Above $90^{\circ} \mathrm{C}$ (form III) the only well defined bands can be ascribed to the nickel cyanide network vibrations.

$\begin{array}{lcc} & \text { TABLE I } & \\ & \begin{array}{c}\text { Room temperature } \\ \text { (form I) }\end{array} & \begin{array}{c}80{ }^{\circ} \mathrm{C} \\ \text { (form II) }\end{array} \\ & - & - \\ \mathrm{CH}_{2} \text { symmetric bending } \\ \begin{array}{c}\text { frequencies }\left(\mathrm{cm}^{-1}\right) \\ \mathrm{CH}_{2} \text { rocking frequencies } \\ \left(\mathrm{cm}^{-1}\right)\end{array} & 1465+1475 & 1465 \\ \end{array}$

Table II gives X-ray powder diffraction data of form I $(n=12)$.

\section{TABLE II}

$d$ obs $(\AA)$ at room temperature in form I of $\mathrm{C}_{12} \mathrm{NH}_{2}-\mathrm{Ni}$ cyanide compound

$\begin{array}{lll} & - & - \\ 16.3 \mathrm{vs}, \text { sharp } & 4.20 \mathrm{vvs} & 2.42 \mathrm{w} \\ 9.56 \mathrm{vw} & 4.04 \mathrm{w} & 2.37 \mathrm{w} \\ 8.10 \mathrm{vs}, \text { sharp } & 3.67 \mathrm{~s} & 2.30 \mathrm{w} \\ 7.16 \mathrm{~m} & 3.21 \mathrm{w} & 2.20 \mathrm{w} \\ 6.72 \mathrm{vvw} & 3.09 \mathrm{w} & 2.15 \mathrm{w} \\ 6.39 \mathrm{vvw} & 2.74 \mathrm{w} & 2.09 \mathrm{w} \\ 5.40 \mathrm{~s}, \mathrm{sharp} & 2.66 \mathrm{w} & 1.85 \mathrm{w} \\ 5.02 \mathrm{~s} & 2.51 \mathrm{~m} & 1.72 \mathrm{w} \\ 4.83 \mathrm{~s} & 2.49 \mathrm{w} & 1.67 \mathrm{w} \\ 4.32 \mathrm{w} & 2.47 \mathrm{w} & 1.62 \mathrm{w}\end{array}$

Attempts to calculate a satisfactory unit cell were unsuccessful. The diffraction lines have different temperature evolutions :

$1^{\circ}$ Some $(16.3,8.10,5.40 \ldots)$ are sharp and considerably enhanced when the samples are prepared by sedimentation from a liquid suspension; these can be ascribed to the successive orders of reflexion for the basal spacing from 16.2 to $18.0 \AA$ at $\sim 60{ }^{\circ} \mathrm{C}$ and from 18.0 to $19.0 \AA$ at $\sim 90{ }^{\circ} \mathrm{C}$;

$2^{\circ}$ Some lines $(7.16,5.02 \ldots)$ remain practically unchanged, the corresponding values of the interplanar distances are those (already known) characteristic of $\mathrm{Ni}-\mathrm{Ni}$ distances in the $\mathrm{Ni}$ cyanide planes;

$3^{0}$ The strongest line in form I, namely at $4.2 \AA$ (a well known characteristic distance in the closed packing of paraffin chains [13]) is no longer present in form II ; in form III, only the lines referred to in $1^{\circ}$ and $2^{\circ}$ are present.

The II $\rightarrow$ III changes in the X-ray diffractogram are reversible on cooling between 110 and $70^{\circ} \mathrm{C}$, while changes corresponding to II $\rightarrow$ I between $80^{\circ} \mathrm{C}$ and room temperature are more sluggish.

The increase of the basal spacing at the first transition temperature $\left(\sim 60^{\circ} \mathrm{C}\right)$ can be related to an increase of the van der Waals repulsion envelopes of the chains (calculated chain length $\sim 18.9 \AA$ ) : the disappearance of splitting in the IR spectrum suggests a loss of coupling between $\mathrm{CH}_{3}$ and/or $\mathrm{CH}_{2}$ groups of neighbouring chains. Prior to the second transition temperature $\left(\sim 90^{\circ} \mathrm{C}\right)$, the thermograms suggest (Fig. 1 $A$, line ab) that the number of accessible states (configurations) of the chain-molecules increases progressively and cooperatively until all these molecules (which are still regularly (viz., crystallographically) bonded to the Ni cyanide two-dimensional network), present no other crystal-like character. The approximate $4: 1$ ratio of the enthalpies (and roughly of the entropies) associated with the two successive transitions shows that the solid-solid $(\mathrm{I} \rightarrow$ II) phase transition is a much more important step in disordering the crystal-like arrays of chains of polymorph I than the subsequent (II $\rightarrow$ III) transition or melting of the already disordered array within the interlayer space.

The following basal spacings $d$ have been measured :

\begin{tabular}{ccccccc}
\multicolumn{7}{c}{ TABLE III } \\
\\
& & $\mathrm{C}_{12}$ & $\mathrm{C}_{13}$ & $\mathrm{C}_{14}$ & $\mathrm{C}_{15}$ & $\mathrm{C}_{16}$ \\
$d(\AA)$ & Form I & -16.2 & - & - & - & - \\
& Form II & 18.0 & & 18.0 & 18.9 & 19.7 \\
& Form III & 19.0 & & 20.0 & & 22.0 \\
& & & & 21.2 & & 23.5
\end{tabular}

Table III shows a linear increase of $d$ with $n$ in the three forms. Assuming for the alkyl chains in form I a fully stretched configuration, this rate of increase leads to an angle of $\sim 45^{\circ}$; using this value, the calculated basal spacing :

$$
\begin{aligned}
d_{\text {Icalc. }}=(\mathrm{Ni}-\mathrm{N})+(\mathrm{N}-\mathrm{C}) \sin \alpha_{\mathrm{I}}+(n-1) \times \\
\times(\mathrm{C}-\mathrm{C})^{*} \sin \alpha_{\mathrm{I}}+r_{\mathrm{CH}_{3}}+\delta
\end{aligned}
$$

where $\mathrm{Ni}-\mathrm{N}: 2.1 \AA[7]$,

$\mathrm{N}-\mathrm{C}=1.47 \cos \left(\frac{180-109.5^{\circ}}{2}\right)$
$(\mathrm{C}-\mathrm{C})^{*}=1.54 \cos \left(\frac{180-109.5^{\circ}}{2}\right)$,
$r_{\mathrm{CH}_{3}}=2.0 \AA$ (van der Waals radius

and

of the $\mathrm{CH}_{3}$ group)

$\delta=\frac{1}{2} 3.2 \AA=$ half thickness

of the $\mathrm{Ni}(\mathrm{CN})_{2}$ planes [14]

is in excellent agreement with $d_{\mathrm{I}}$ observed. 
The assumption of fully stretched alkyl chains in form II would similarly lead to $\alpha_{\text {II }} \sim 53^{\circ}$; however,

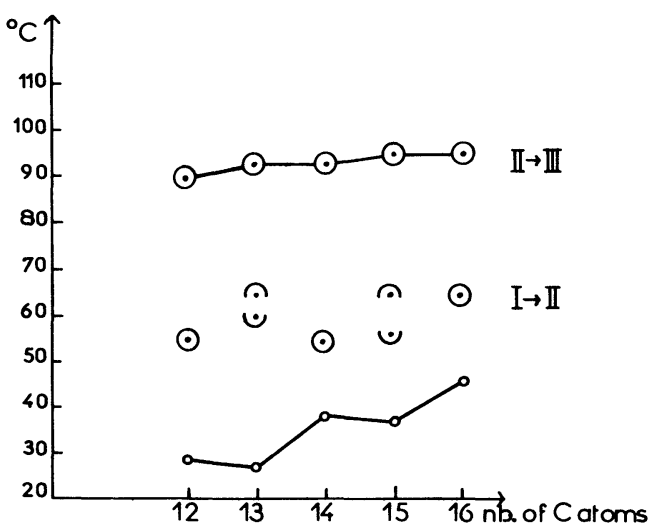

Fig. 3. - Transition and melting temperature : $\bigcirc$ Melting of the pure amines $\mathrm{C}_{n} \mathrm{H}_{2 n+1} \mathrm{NH}_{2} n=12$ to $16 . \odot$ In layer transition and melting of the amines in the corresponding $\mathrm{Ni}$ cyanides compounds.
X-rays and infra-red spectra do not fully support this assumption in the case of form II and certainly exclude it in the case of form III.

In figure 3, the transition and melting temperatures (defined as the beginning of the DTA signal) are given for the cyanide compounds with $n=12$ to 16 ; they are always above the melting temperature of the corresponding pure $n$ alkylamines. For the $\mathrm{C}_{13}$ and $\mathrm{C}_{15}$ compounds, the DTA thermograms show a splitting of the I $\rightarrow$ II endotherm, the relative intensity of the $A \alpha$ and $A \beta$ signals (Fig. $2 B$ ) depending on the thermal history. Moreover, upon cooling, these complexes revert back to form I much more easily than the even complexes. This versatile behaviour seems to be consistent with the Walker hypothesis [11] concerning the existence of two distinct conformations in the complexes with odd intercalates.

We thank Dr. Setton for helpful discussions.

\section{References}

[1] Groupe français d'étude des Carbones, Les Carbones (Masson) 1965, Vol. II.

[2] Gamble, F. R., Osiecki, J. H., Lais, M., Pisharody, R., Disalvo, F. J. and Geballe, T. H., Science 174 (1971) 493.

[3] Weiss, A. and Ruthardt, R., Z. Naturforsch. 28 b (1973) 249.

[4] Pfirrmann, G., Lagaly, G. and Weiss, A., Clays and Clay Miner. 21 (1973) 239.

[5] WalKer, G. F., Clay Miner. 7 (1967) 129.

[6] Weiss, A., Chem. Ber. 91 (1958) 487.
[7] Rayner, J. H. and Powell, H. M., J. Chem. Soc. 3412 (1958).

[8] Weiss, A. and FranCK, R., Kolloid-Z. 177 (1961) 47.

[9] LudI, A. and HüGI, R., Helv. Chim. Acta. 50 (1967) 1283.

[10] Mathey, Y. and Mazières, C., Can. J. Chem. 52 (1974) 3637.

[11] Walker, G. F. and Hawthorne, D. G., Trans. Faraday. Soc. 63 (1966) 166.

[12] Submitted for publication in Inorg. Nucl. Chem. Lett.

[13] MülleR, A., Trans. Faraday Soc. 29 (1933) 990.

[14] Vegas, A., Santos, A. and RuIz Amil, R., An. Quim 70 (1974) 214. 